\title{
First record of spine malformation of the round stingray Urobatis halleri off the Western Coast of Baja California Sur, México
}

\author{
M. R. Ochoa-Díaz ${ }^{1}$ J. Rodriguez-Romero ${ }^{1 *}$, J. López-Martínez and M. C. Maldonado-García
}

\begin{abstract}
Background: Malformations of the Round stingray Urobatis hallerii, Cooper 1863 captured off the southwestern coast of Baja California Sur, México are reported in this study.

Methods: The ray was an adult male captured by artisanal fishery in the area of Estero Banderitas. Size measurements of total length and disk width were taken; the organism could be photographed when captured.

Results: Malformations of $U$. hallerii were found in the posterior part of the spine, a distortion in the upper part of the tail and in the left fin close to the tail. The specimen was considered able to reach the adult size usually reported in other specimens of this species despite the spine malformations because of its benthic habits and not losing its mobility completely.
\end{abstract}

Conclusions: The observed malformations were likely due to genetic alterations although other studies are needed to see if other environmental factors could cause malformations in marine organisms mainly in fish and elasmobranchs.

Keywords: Malformation, Spine, Urobatis hallerii, Western coast, Baja California Sur

\section{Background}

Elasmobranch fisheries have a great economic potential in the coasts of Mexico. One of them is the Round stingray Urobatis halleri, Cooper 1863 that belongs to the family Urolophidae. Its distribution range is in tropical and temperate warm areas, usually shallow waters, lagoons, and estuaries McEachran JD 1995. The size of the species is small growing up to $55 \mathrm{~cm}(31 \mathrm{~cm}$ disk width) Allen \& Robertson 1994. U. halleri has isometric growth showing it increases in weight and disk width in equal proportion. It is a benthic opportunist predator that consumes shallow infauna and epifauna in its foraging areas highly dominated by the presence of crustaceans, which are its preferred food Castellanos-Cendales 2009. Our record describes the first spine malformation

\footnotetext{
* Correspondence: jrodri04@cibnor.mx

'Centro de Investigaciones Biológicas del Noroeste, S.C. Av. Instituto Politécnico Nacional 195, Playa Palo de Santa Rita Sur, La Paz, B.C.S C.P. 23096, México Full list of author information is available at the end of the article
}

of the $U$. halleri found off the western coast of Baja California Sur (BCS), Mexico. In different studies performed on elasmobranchs, malformations in bathoids have been less frequent compared with chondrichthyes Devadoss P 1983. For example, some of the cases found in rays have been functional bicephalia in Rhinoptera steindachneri (Castro-Aguirre \& Torres-Villegas 1979); morphological abnormality in Dasyatis guttata, Blonch \& Schneider, 1801 (Gaitán-Espitia \& López-Peña 2008) and in D. longa Escobar-Sánchez et al. 2009; albinism in Myliobatis californica, Gill, 1865 De Jesus-Roldan 1990; and an ocular malformation in $U$. halleri RodríguezRubio et al. 2010.

\section{Methods}

In a sampling performed with an 8-mm gillnet within Estero Banderitas off the western Pacific coast of BCS, Mexico (24 $50^{\prime}-25^{\circ} 00^{\prime} \mathrm{N}$ and $112^{\circ} 05^{\prime}-112^{\circ} 08^{\prime} \mathrm{W}$ ) (Fig. 1a), a specimen of $U$. halleri was captured by local

\section{Bïomed Central}

(C) 2016 The Author(s). Open Access This article is distributed under the terms of the Creative Commons Attribution 4.0 International License (http://creativecommons.org/licenses/by/4.0/), which permits unrestricted use, distribution, and reproduction in any medium, provided you give appropriate credit to the original author(s) and the source, provide a link to the Creative Commons license, and indicate if changes were made. The Creative Commons Public Domain Dedication waiver (http://creativecommons.org/publicdomain/zero/1.0/) applies to the data made available in this article, unless otherwise stated. 


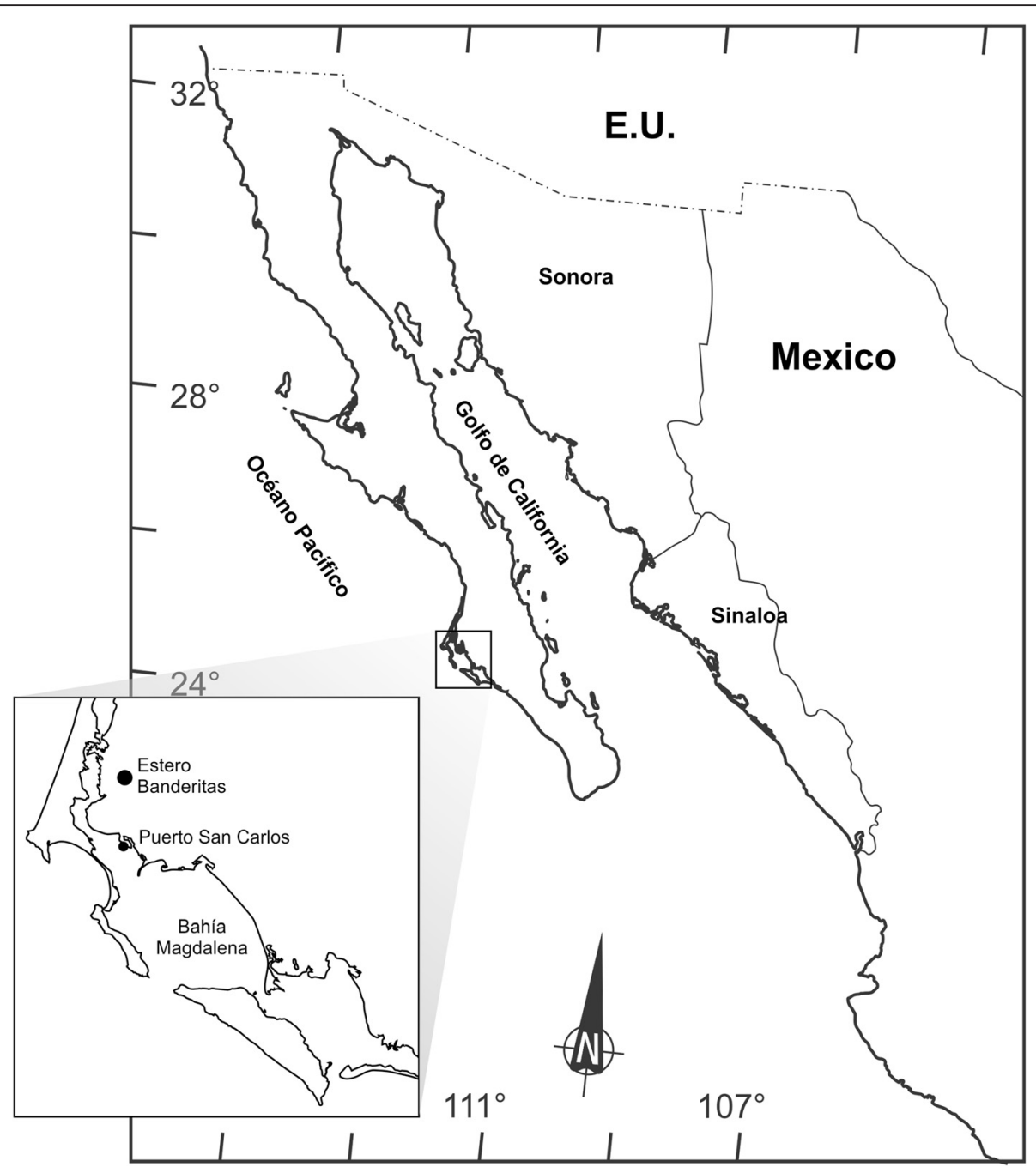

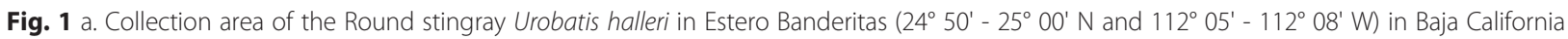
Sur, Mexico

fishermen at a distance of four kilometers from the coast in the morning of September 2004. The sampled organism of $U$. halleri was an adult male. Only size measurements were taken, and it was photographed when captured. The photographs are found in collection of the Fish Ecology Laboratory with number EP. 010 at Centro de Investigaciones Biológicas del Noroeste in La Paz, BCS, México.

\section{Results}

While observing the organism, malformations were found in the posterior part of the spine (Fig. 2a), a partial distortion in the left fin and upper part of the tail, and in the left fin close to the tail (Fig. 2b). The disk coloration was also observed darker toward the center compared to a normal ray. In addition, the spots and their color were evident but toward the extreme parts of the disk. Some of the measurements taken were total length $35 \mathrm{~cm}$, disk length $18 \mathrm{~cm}$, disk width $28.5 \mathrm{~cm}$, tail length $17 \mathrm{~cm}$, and total weight $750 \mathrm{gr}$.

\section{Discussion}

According to the malformations recorded in elasmobranchs, Berzins et al. 2002 identified at least 35 cases of dorsal spine malformations in sharks in their environment and in those in captivity. The most frequent were found in the sandbar shark (Carcharhinus plumbeus), which showed these malformations could be due to different origins or causes, such as nutritional imbalance, muscle diseases, or atypical biochemical stress.

Some studies on malformations of rajiforms, as that of Escobar-Sánchez et al. 2009 who made a report of the first record of an anomaly in D. longa in the Gulf of California, Mexico, highlighted that malformation could be caused by adverse environmental conditions during 

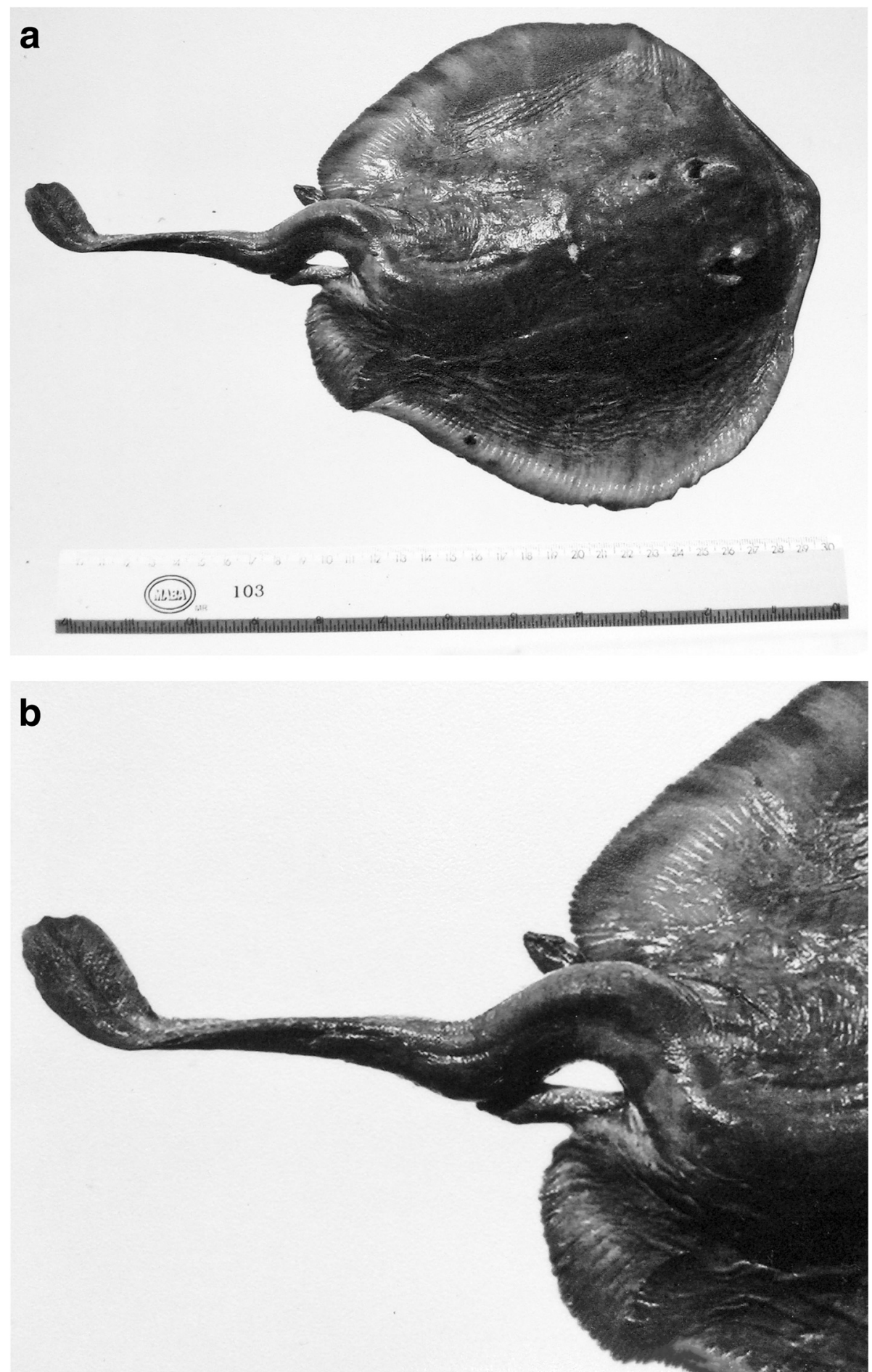

Fig. 2 a. Dorsal view of spine malformation of Urobatis halleri, Cooper 1863, captured off the western coast of Baja California Sur, Mexico. b. View of upper part of the tail malformation of Urobatis halleri captured off the western coast of Baja California Sur, México

embryonic development. However, the causes of morphological malformations were difficult to explain because further research is necessary.
Mancini et al. 2006 concluded that malformations could be due to climate change; they also reported that possible causes could be lesions, tumors, or parasite 
infections. None of the samples showed evidence of any of these causes.

Rodríguez-Rubio et al. 2010 performed a study in 30 specimens of $U$. halleri for the Gulf of California, and they found an ocular malformation and dark mucus in the dorsal surface and in some portions of the ventral side. Their conclusion was that organisms with this bnormality could have reached maturity because they use the electroreceptor system to feed and not their eyes to detect prey (cladocerans and polychaetes) CastellanosCendales 2009. Some of the malformations in shark can also be related to contamination. It is worth to mention that although the western coast of BCS is considered a pristine area, it has important mineral deposits that could contribute to high variations in heavy metal concentration Shumilin et al. 2000.

In our area of study, works have been carried out on heavy metals mainly on mercury, copper, zinc, cadmium, and selenium in rays' (Raja velezi and Gymnura marmorata) and sharks' (Sphyrna zygaena, Prionace glauca, Isurus oxyrinchus, Alopias pelagicus, Carcharhinus limbatus) muscle, liver, and kidney, in which acceptable values for human consumption have been found. However, the authors have recommended to carry out more studies in other organs of these and others species Barrera-García et al. 2012; Escobar-Sánchez et al. 2011, more so in vulnerable stages of their life cycle. FríasEspirueta et al. Frías-Espirueta et al. 2015 carried out studies in females and embryos of Rhizoprionodon longurio concluding that $\mathrm{Hg}$ could affect normal embryonic development.

The malformations observed in $U$. halleri could be attributed to genetic abnormalities because of the characteristics shown in the spine and fin besides the coloration observed during its capture. Nevertheless, other effects have not been dismissed.

\section{Conclusion}

Studying the effects of heavy metals on the different developmental stages of $U$. halleri to determine the causes of the malformations is highly recommended. This species of coastal habits spends most of the time buried in mud or beneath the sand for feeding, protection, reproduction, or other purposes, so if the environmental conditions are not optimal, the likelihood of being affected by contaminants increases. Despite the malformations of the Round stingray specimen in our study, they were not an obstacle for the species to complete its development.

\section{Abbreviations}

BCS, Baja California Sur; U, Urobatis

\section{Acknowledgments}

The authors would like to thank the fishermen from Estero Banderitas for allowing us to take measurements and photograph the specimen and
D. Dorantes for English edition. Also the mexican project SAGARPA_CONACYT-179-2003-2007: "Distribución, abundancia y evaluación del potencial pesquero de la ictiofauna béntico-demersal de la Plataforma Occidental de la Península de Baja California Sur, México".

\section{Funding}

This work was financed by the SEP-CONACYT 03 (2004-2007) Project: "Biology and Ecology of benthonic Fish the southwestern coast of Baja California Sur".

\section{Authors' contributions}

JR Project Director, collection and identification of organisms. MR Writing the note. JL Note revisions and corrections. MM Note observations. All authors read and approved the final manuscript.

\section{Competing interests}

The authors declare that they have no competing interests.

\section{Author details}

${ }^{1}$ Centro de Investigaciones Biológicas del Noroeste, S.C. Av. Instituto Politécnico Nacional 195, Playa Palo de Santa Rita Sur, La Paz, B.C.S C.P. 23096, México.

${ }^{2}$ Centro de Investigaciones Biológicas del Noroeste, S.C. Km 2.35 Carretera a Las Tinajas, S/N Colonia Tinajas, Guaymas, Sonora C. P. 85460, México.

Received: 30 June 2016 Accepted: 1 July 2016

Published online: 01 August 2016

\section{References}

Allen GR, Robertson DR. Fishes of the tropical eastern Pacific. USA. Honololu, Hawaii: University of Hawaii Press; 1994. p. 35.

Barrera-García A, O'Hara T, Galván-Magaña F, Méndez-Rodríguez LC, Castellini JM, Zenteno-Savín T. Oxidative stress indicators and trace elements in the blue shark (Prionace glauca) off the east coast of the Mexican Pacific Ocean. Comparative Biochemistry and Physiology Part C. Toxicology \& Pharmacology 2012;156(2):59-66.

Berzins IK, Walsh M, Richards M. Spinal deformities in captive sandtiger sharks (Carcharias taurus). In: Saitoh S, Takahashi I, Mizoguchi I, Sasano Y, Kagayama M, editors. The American Elasmobranch Society. Norman OK, USA. Proceedings of the 27th Annual Eastern Fish Health Workshop. SC, USA: Mount Pleasant; 2002. p. 18-20.

Castellanos-Cendales L. Hábitos alimenticios de Urobatis halleri y Urotrygon chilensis (Chondrichthyes: Urolophidae), en Sinaloa, México. UNAM, Instituto Nacional de Pesca-CRIP-Mazatlán, México: Tesis de posgrado; 2009.

Castro-Aguirre JL, Torres-Villegas JR. Sobre un caso de bicefalia funcional en Rhinoptera steindachneri Evermann and Jenkins (Chondrichthyes, Elasmobranchii, Batoidea), capturado en la costa occidental de Baja California, México. Ciencias Marina. 1979;6:27-41.

De Jesus-Roldan M. An albino bat ray, Myliobatis californica, from the Pacific coast of Baja California Sur, Mexico. Calif Fish Game. 1990;76(2):126-7.

Devadoss P. On some specimens of abnormal elasmobranchs. Ichthyological notes. Matsya. 1983;9:486-488.

Escobar-Sánchez O, Galván-Magaña F, Downton-Hoffmann CA, Carrera-Fernández M, Alatorre-Ramírez VG. First record of a morphological abnormality in the longtail stingray Dasyatis longa (Myliobatiformes: Dasyatidae) in the Gulf of California, Mexico. Marine Biodiversity Records. 2009;2:1-3.

Escobar-Sánchez O, Galván-Magaña F, Rosíles-Martínez R. Biomagnification of Mercury and Selenium in Blue Shark Prionace glauca from the Pacific Ocean off Mexico. Biological Trace Element Res. 2011;144:1-3.

Frías-Espirueta MG, Zamora-Sarabia FKG, Márquez-Farías JF, Osuna-López Jl, Ruelas-Inzunza J, Voltolina D. Total mercury in female Pacific sharpnose sharks Rhizoprionodon longurio and their embryos. Lat Am J Aquat Res. 2015; 43(3):534-8.

Gaitán-Espitia J, López-Peña A. Presence of young blacktip sharks Carcharhinus limbatus (Carcharhiniformes: Carcharhinidae) in the north area of the Tayrona ecoregion, Colombian Caribbean. Lat Am J Aquat Res. 2008:36:115-9.

Mancini PL, Casas AL, Amorim AF. Morphological abnormalities in a blue shark Prionace glauca (Chondrichthyes: Carcharhinidae) foetus from Southern Brazil. J Fish Biol. 2006;69:1881-84.

McEachran JD. Dasyatidae. Rayas-látigo. Guia FAO para Identificación de Especies para los Fines de la Pesca. In: Fischer W, Krupp F, Schneider W, 
Sommer C, Carpenter KE, Niem V, editors. Pacifico Centro-Oriental, vol. 3. Rome: $\mathrm{FAO} ; 1995$. p. $752-5$

Rodríguez-Rubio U, Navarro-González AJ, Vergara-Solana JF. First record of black mucus and ocular malformations in the round stingray Urobatis halleri

(Rajiformes: Urotrygonidae) at the southern Gulf of California, México. Marine Biodiversity Records. 2010;3:1-3.

Shumilin EN, Rodríguez-Figueroa G, Bermea OM, Baturina EL, Hernández E, Meza GDR. Anomalous trace element composition of coastal sediments near the copper mining district of Santa Rosalía, Península of Baja California, Mexico. Bull Environ Contamin Toxicol. 2000;65:261-8.

Submit your next manuscript to BioMed Central and we will help you at every step:

- We accept pre-submission inquiries

- Our selector tool helps you to find the most relevant journal

- We provide round the clock customer support

- Convenient online submission

- Thorough peer review

- Inclusion in PubMed and all major indexing services

- Maximum visibility for your research

Submit your manuscript at www.biomedcentral.com/submit 